\title{
ВИКОРИСТАННЯ КЕЙС-МЕТОДУ У ПРОФЕСІЙНІЙ ПІДГОТОВЦІ МАЙБУТНІХ МОРСЬКИХ ФАХІВЦІВ ПРИ ВИВЧЕННІ АНГЯІЙСЬКОЇ МОВИ
}

У статті облрунтовано необхідність використання кейс-методу в професійній підготовці майбутніх морських фахівців при вивченні англійської мови. Визначено важливість вивчення англійської мови майбутніми спеціахістами морської галузі в умовах сьогодення.

3'ясовано, щьо кейс-метод активно застосовуеться у закладах освіти морського профілю, оскільки відповідае потребам нинішнього часу $i$ несе в собі великі можливості щодо професійного розвитку особистості майбутнього морського фахівия. Схарактеризовано необхідні навички майбутніх спеціалістів, які формуються при використанні кейс-методу, такі як: чітке виконання поставленої мети та завдання, вміння формулювати протилежну точку зору, вміння аргументувати та захищати власну думку, критично мислити, знаходити рішення в умовах обмеженого часу.

Автор наголошуе, щь мета застосування кейс-методу при вивченні морської англійської мови має бути обьрунтованою та значною, оскільки робота з кейсом повинна зацікавити студентів завдяки напруженості ситуації, конфлікту та драматичності. Визначено зміст морського кейса, який має відображати навчальні ціиі, містити дозовану інформаціюо, щоб студенти швидко зрозуміли суть проблеми, та надавати необхідні дані для ї вирішення. Виявлено особливості роботи над кейсом, у процесі якої студенти повинні використовувати отриманні знання та проявляти свої особисті якості, такі як: здатність демонструвати рівень бачення професійної ситуації, рівень володіння морською англійською мовою та ін.

Сформульовано послідовні кроки опрацювання змісту кейса морської тематики та чинники ефективної роботи, які залежать від якості самого кейса, рівня професійної підготовленості студентів та готовності викладача. Розглянуто типи кейсів, які необхідно використовувати при вивченні морської англійської мови. Подано визначення кейса морської тематики як єдиного інформаційного комплексу; опису подій, що містить певну проблемну ситуацію, яка потребує обговорення та прийняття обьрунтованого вирішення.

Схарактеризовано кейс-метод як інтерактивний метод навчання, метод аналізу ситуацій, який надае змогу наблизити процес навчання до реальної професійної діяльності морських фахівців.

Ключові слова: кейс, кейс-метод, професійна підготовка, морська англійська мова, майбутні морські фахівиі, практичне заняттял, викладач, навички.

Постановка проблеми. Новітні стратегії розвитку морського ринку праці, вимоги роботодавців, робота на сучасних суднах світового флоту в багатонаціональних екіпажах призводять до перегляду системи професійної підготовки майбутніх морських фахівців. При цьому надзвичайно важдивого значення набуває цілеспрямована організація навчального процесу, враховуючи використання ефективних методів навчальної діяльності.

Здатність особистості володіти іноземною мовою належить до переліку загальних ключових компетентностей сучасної дюдини. Цей факт у повній мірі стосується й майбутніх морських фахівців. В умовах сьогодення майбутні морські спеціалісти

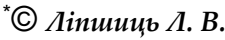

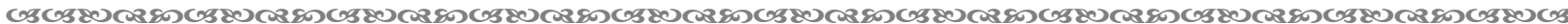


розуміють необхідність вивчення іноземної мови, головне місце серед яких посідає англійська.

Загальновідомо, що навчання іноземній мові (зокрема, англійській) - це гнучкий інформаційно-освітній процес, де зберігається підвищена увага не тільки до нових освітніх технологій та педагогічних інновацій, але й використовуються традиційні методи. Однією із інноваційних технологій навчання є кейс-метод.

Аналіз досліджень. Сьогодні кейс-метод активно застосовується у закладах освіти морського профілю, оскільки відповідає потребам часу і несе в собі великі можливості, зокрема щодо професійного розвитку особистості майбутнього морського фахівця.

Аналіз наукових джерел свідчить, що проблему використання кейс-методу упроцесі викладання різних дисциплін висвітлювали Т. Аргунова [1], В. Вишнопольська [2], В. Кудрявцева [4], В. Смелікова [5], Е. Стрига [6], I. Форостюк [7] та ін. Науковці зазначають, що саме використання кейс-методу дозволяе майбутнім спеціалістам розвинути необхідні навички, такі як: чітке виконання поставденої мети та завдання, вміння формулювати протилежну точку зору, вміння знаходити аргументи та захищати власну думку, критично мислити, швидко знаходити рішення в умовах обмеженого часу.

Так, О. Каніболоцька вважає, що ефективність технології кейс-стаді подягає в тому, що за допомогою даного методу формується уміння організовувати діядьність й обирати форми досягнення результатів, максимально використовуючи бажання і здібності дюдей; застосування кейс-стаді замінює пасивний тип навчання, в якому студенту відводиться роль слухача, активним навчанням, де студент стає активним генератором творчих знань і конструктивних рішень; ця технологія створює умови для перетворення знань із бездікої інформації, отриманої шляхом механічного заучування, на особистий досвід студентів [3, с. 203].

Мета статті полягає в обгрунтуванні необхідності використання кейс-методу у процесі професійної підготовки майбутніх морських фахівців при вивченні ангдійської мови.

Виклад основного матеріалу. Мета застосування кейс-методу при вивченні морської ангдійської мови має бути обгрунтованою та значною, оскільки робота 3 кейсом повинна зацікавити студентів завдяки напруженості ситуації, конфдікту та драматичності. Тому, зміст морського кейса має відображати навчальні цілі, містити дозовану інформацію, щоб студенти швидко зрозуміли суть проблеми, та надавати необхідні дані для іiі вирішення. Під час роботи над розв'язанням морського кейса студенти повинні не тільки використовувати вже отриманні знання, але й проявляти свої особисті якості, такі як: здатність демонструвати рівень бачення професійної ситуації, рівень володіння морською ангдійською мовою та ін.

Зважаючи на те, що кейс-метод - це технологія контекстного навчання та алгоритмізований процес, основною метою якого є вирішення певної ситуації, організація роботи 3 ним повинна бути чітко структурована. Тому не рекомендуеться порушувати послідовність етапів роботи.

У цілому сформульовано кілька послідовних кроків опрацювання кейса, а саме:1) обговорення питань, представлених перед текстом, які зачіпають загальні питання та вимагають від майбутніх спеціалістів теоретичних знань за основним фахом; 2) індивідуальна самостійна робота 3 матеріалами кейса, представленими у вигляді тексту або аудіо/відео файлу (в залежності від рівня підготовленості); 3) обговорення питань після тексту кейса, які стосуються аналізу представленої інформації, з метою перевірки рівня розуміння прочитаного або почутого тексту; 4) робота в неведиких групах по обговоренню кдючової проблеми; 5) представлення результатів обговорення 
в малих групах на загальній дискусії; 6) виконання вправ, спрямованих на відпрацювання лексичних і граматичних труднощів, з якими можуть зіткнутися студенти; 7) написання summary - короткого викладу матеріалу або conclusion закдючного узагальнення; 8) підготовка презентації і виступ за матеріалами кейса англійською мовою [3, с. 204].

Вважаємо, що ці етапи можна успішно використовувати в ході опрацювання змісту кейса морської тематики.

Зазначимо, що роботу над кейсом доречно планувати як на практичному занятті заключного етапу вивчення певної морської теми, так i у процесі опанування навчального матеріалу; а також під час проведення уроків-дискусій або дебатів 3 актуальних питань професійної направленості, організації як діалогічної, так і полілогічної мовленнєвої діяльності, проєктної роботи.

Ми погоджуємось 3 точкою зору Н. Черненко, що практичне заняття є основною формою для реалізації кейс-технологій, на якому погдиблюються та закріплюються знання 3 фахових і гуманітарних дисциплін, удосконалюються вміння та навички комунікації, формується мотивація до активного професійно-орієнтованого спілкування. Практичні заняття проводяться у невеликих групах, що сприяе встановленню атмосфери активної взаємодії та комунікації [8, с. 12].

Оскільки кейс-метод має комплексний характер і містить всі види мовленнєвої діяльності, використання його на заняттях 3 морської англійської мови є цілком доречним. Успішна та ефективна робота над кейсом морської тематики залежить від якості самого кейса, рівня професійної підготовленості студентів та готовності викдадача, який виступає як помічник, консудьтант та організатор, завданням якого є допомагати студентам швидко вирішувати проблеми, організовувати дискусію та обговорення, вміло допомагати та спрямовувати хід роботи. Тож, майбутні морські фахівці отримають користь від роботи над кейсом, якщо вони братимуть активну участь у дискусії та обговоренні. Для того, щоб підготуватися до обговорення кейса в аудиторії, студентам необхідно вивчити факти, зробити висновки 3 даних фактів, оцінити альтернативні дії в певній ситуації та зробити вибір на користь того чи іншого плану дій, бути готовими представити свої думки під час обговорення в аудиторії, відстояти свої погляди або переглянути початкове рішення.

Нам імпонує наукова позиція В. Кудрявцевої про те, що «кожну навчальну тему програми варто забезпечувати декількома кейсами для різнобічного обговорення схожих проблемних ситуацій в управлінні судном» [4, с. 175].

Робота над розв'язанням кейса допомагає майбутнім морським фахівцям отримати підгрунтя для перевірки теоретичних знань та дослідження ідей, визначення закономірностей, взаємозв'язків, обгрунтування гіпотез щодо ианцюга розвитку подій; якісно та гдибше зрозуміти тему, розвинути уявлення; підвищити зацікавленість незвичайною ситуацією, що виникла на борту судна; сприяти процесу мислення та дискусії щодо розвитку подій, які призвели до аварійної ситуації; перевірити власні погляди; згенерувати, розвинути і застосувати критичне, аналітичне, стратегічне і творче мислення; отримати додаткову інформацію професійного характеру; сформувати вміння вирішувати практичні проблеми та запропонувати альтернативні рішення, робити раціональні висновки, у тому числі в нестандартних ситуаціях; поєднати теоретичні знання з реаліями життя та професійної діяльності, перетворити абстрактні знання у вміння з метою збереження безпеки під час роботи у багатонаціонадьній команді на борту закордонного судна; сформувати комунікативні навички спілкування в багатонаціональному екіпажі. Сприяе цьому й те, що для роботи 3 кейсом необхідно підбирати автентичні тексти, такі як: газетні та журнадьні статті, репортажі 3 місця 
подій, уривки 3 художніх творів, рекламні оголошення, звіти про розслідування морських аварій, спогади капітанів тощо. Кейси, доповнені таблицями, ілюстраціями, фото $з$ місця події, відео та аудіо матеріалами, є цікавими для роботи.

На наш погляд, у процесі вивчення морської англійської мови особливої уваги заслуговуютьнаступні такі типи кейсів: кейс-випадок, кейс-вправа і кейс-ситуація. Детальніше розглянемо ці типи.

Кейс-випадок - це короткий текст, в якому розповідається про окремий випадок. Під час проведення практичних занять 3 морської англійської мови слід використовувати такий кейс, щоб проілюструвати певну ідею або актуалізувати питання для обговорення. Отже, студентам не треба готуватися до обговорення вдома, оскільки кейс-випадок можна прочитати дуже швидко.

Для проведення кількісного аналізу слід використовувати кейс-вправу, що надає майбутнім морським фахівцям можливість застосовувати на практиці здобуті навички. Студенти мають мождивість зануритись у ситуацію та в ході пізнавадьної діяльності представити свої думки, використовуючи творчий підхід, адже робота над кейс-вправою може здійснюватися у декілька етапів. Отже, опрацювання майбутніми морськими фахівцями кейс-вправи сприяе розширенню професійних знань, покращенню здатності спілкуватися морською англійською мовою, розвитку винахідливості.

Під час роботи 3 кейс-ситуацією студенти найчастіше відповідають на запитання: «Чому ситуація набула такого розвитку і як можна виправити становище?», тому що такий кейс вимагає від студентів аналізу ситуації.

Як правило, студентам пропонується реальна кейс-ситуація, найчастіше у вигдяді звіту про аварію, яка виникла на борту закордонного судна, після вивчення відповідного навчального модуля. Спільна діяльність викладача та студентів дозволяе розробити спосіб вирішення. Якщо кейс містить фото з місця подій, студентам спочатку необхідно розглянути його і відповісти на запитання та проаналізувати, що саме призвело до аварії. Завдяки такому завданню студенти використовують наявний у них обсяг теоретичних знань. Потім під час самостійної роботи вони ознайомлюються з повним текстом кейсу.

Аналіз подій та умов, які призвели до аварійної ситуації на судні, здійснюється послідовно за чітким алгоритмом та включае декілька етапів. По-перше, відповіді студентів на питання після тексту кейса дозволяють перевірити, наскільки вони зрозуміли прочитане та як аналізують інформацію, подану у кейсі. По-друге, обговорення основної проблемної ситуації може бути проведено в невеликих групах. Результатом обміну думками може бути розуміння мотивів, які призвели до негативних наслідків. По-трете, на завершальній стадії роботи 3 кейс-ситуацією студентам необхідно запропонувати розповісти, як би вони поведи себе у подібній ситуації, тобто студентам необхідно визначити альтернативні шляхи для запобігання небезпечного випадку, розробити план їх реалізації.

Треба зазначити, що використання кейс-методу буде ефективним, якщо застосовувати його нарівні 3 іншими методами. При цьому важдиво додати, що об'єктивний мінімум або максимум кейсів, які визначають цілісність курсу морської англійської мови та досягнення поставлених навчальних цілей, залежать від інтелектуального та освітнього рівня студентів, а також від освітньої програми.

Наш досвід свідчить, що необхідно використовувати кейси короткі та довгі, які викладаються конкретно або узагальнено, але, при цьому зміст кейса має відображати навчальні цілі. Дуже важдивим є утримання від надмірно насиченої інформації та інформації, що не має безпосереднього відношення до теми, яка вивчається. У цілому кейс має містити дозовану інформацію, яка дозволяє студентам 
швидко зрозуміти суть тієї чи іншої проблеми та надати всі необхідні дані для iї вирішення.

Висновки. Таким чином, кейс морської тематики - це єдиний інформаційний комплекс; опис подій, що містить певну проблемну ситуацію, яка потребує обговорення та обгрунтованого вирішення. Такий кейс складається 3 проблеми, яка має декілька варіантів вирішення, допоміжної інформації, необхідної для аналізу кейса, завдання до нього.

Підсумовуючи вищесказане, можна зробити висновок, що наявність конфліктних суперечок, аргументації, дискусії в структурі кейса морської тематики тренуе студентів обговорювати; навчає системно розібратися у професійній ситуації, дотримуватись етикету спілкування, захищати свою точку зору, переконувати співрозмовників у своїй правоті. Саме тому під час роботи над кейсом морської тематики створюються відповідні умови, завдяки яким студенти здобувають нові знання, використовуючи різні джерела; відпрацьовують комунікативні вміння, працюючи у командах; застосовують набуті знання для вирішення практичних професійних завдань; розвивають вміння дослідження ланцюга подій, такі як: виявлення суті проблеми, збір інформації з різних ресурсів, проведення спостереження та узагальнення, розроблення гіпотези, побудова та представлення альтернативного плану дій, системного та критичного мислення.

Отже, кейс-метод - це інтерактивний метод навчання, метод аналізу ситуації, який надає змогу студентам наблизити процес навчання до реальної професійної діяльності морських фахівців.

Уважаємо, що розгляд питання використання кейс-методу у процесі професійної підготовки майбутніх морських фахівців при вивченні англійської мови наразі є необхідним та заслуговує на подальше вивчення.

\section{Список використаних джерел:}

1. Аргунова Т. Г. Применение кейс-метода в образовательном процессе и методической работе ССУЗА: науч.-метод. пособ. Москва, 2007. 104 с.

2. Вишпольська В.Ф. Застосування кейс-методу у професійній підготовці фахівця 3 міжнародних економічних відносин. Наукові записки. Київ, 2009. Вип. 82. С. 25-33.

3. Каніболоцька О. А. Метод case-study у процесі навчання студентів немовних спеціальностей у вищій школі. Новітні тенденції навчання іноземної мови за професійним спрямуванням: матеріали II Всеукр. наук.-практ. конф. (м. Херсон, 25-26 квіт. 2013 р.). Херсон: ХДМА, 2013. C. 202-205.

4. Кудрявцева В.Ф. Практика використання кейс-методу у вивченні ангдійськоїмови в морському навчальному закладі. Педагогічний альманах: збірник наукових праць / редкол. В. В. Кузьменко (голова) та ін. Херсон: КВНЗ «Херсонська академія неперервної освіти», 2012. Випуск 14. С. 169-175.

5. Смелікова В. Б. Підготовка майбутніх судноводіїв до професійно-орієнтованого спілкування засобами кейс-технодогій: дис. ... канд. пед. наук: 13.00.04 / Херс. держ. ун-т. Херсон, 2017. 305 c.

6. Стрига Е. В. Використання методу case-study у навчанні ангдійської мови студентів немовних спеціальностей. URL: $\quad$ http://dspace.pdpu.edu.ua/bitstream/123456789/7019/1/Stryga\%20 Eleonora\%20Vyacheslavivna\%202013\%204.pdf

7. Форостюк I. В. Використання кейс-методу на заняттях 3 ангдійської мови 3 майбутніми спеціалістами у сфері туризму. URL:http://www.philol.vernadskyjournals.in.ua/journals/2019/ 2 2019/part 1/28.pdf

8. Черненко Н. І. Педагогічні умови реалізації андрагогічного підходу у професійній підготовці робітників морського транспорту: автореф. дис. ... канд. пед. наук: 13.00 .04 / Херс. акад. неперер. освіти. Херсон, 2016. 20 с. 


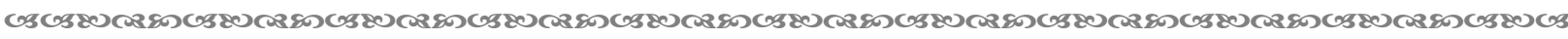
ПЕДАГОГІЧНИЙ АЛЬМАНАХ. - 2021. - ВИПУСК 50

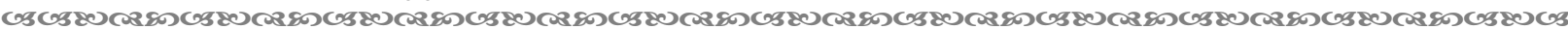

\section{References:}

1. Arhunova, T. G. (2007). Primenenie keis-metoda v obrazovatelnom protsese I metodicheskoi rabote SSUZA [Applying the case method in educational process and methodical work of Specialized Secondary School]. Moskva [in Russian].

2. Vyshpolska, V. F. (2009). Zastosuvaniya keis-metodu u profeciinii pidhotovtci fakhivtcia $\mathrm{z}$ mizhnarodnykh vidnosyn [Applying the casemethod in professional training of a specialist in international relations]. Naukovi zapysky, 82, 25-33 [in Ukrainian].

3. Kanibolotska, O. A. (2013). Metod keis-stadi u protcec inavchannia studentiv nemovnykh spetcialnosteyi $\mathrm{u}$ vychzhii shkoli [Case-study method in the process of teaching non-language students in higher education], Novitni itendentsii navchannia inozemnoyi movy za profesiinym spryamuvaniiam, materialy II Vseukr. nauk.-prakt. konf. [The latest trends in foreign language teaching in a professional field, Proceedings of the 2-nd All-Ukrainian scientific and practical conference]. Kherson [in Ukrainian].

4. Kudryavtseva, V. F. (2012). Praktyka vykorystannia keis-metodu u vyvchenni angliiskoyi movy $\mathrm{v}$ morskomunavchalnomyzakladi [Practice of using of case method in teaching English at maritime training institution]. Pedahohichnyi almanakh, 14, 169-175 [in Ukrainian].

5. Smelikova, V. B. (2017). Pidhotovka maybutnikh sudnovodiiv do profesiino-orientovanogo spilkuvannya zasobamy keis-tekhnologyi [Preparation of future navigators for professionally-oriented communication by means of case-technologies]. (Candidate's thesis). Kherson [in Ukrainian].

6. Stryga, E. V. (2013). Vykorystannia metoda keis-stadi u navchanni angliiskoi movy studentiv ne movnykh spetcialnostei [Using the case-study method in teaching English to non-language students]. Retrieved from http://dspace.pdpu.edu.ua/bitstream/123456789/7019/1/Stryga\%20Eleonora\%20 Vyacheslavivna\%202013\%204.pdf [in Ukrainian].

7. Forostyuk, I. V. (2019). Vykorystannia keis-metodu na zaniattiakh $z$ angliiskoi movy $z$ maibutnimy specialistamy us pheri turyzmu [Using the case-method at English lessons with future specialists of tourism sphere]. Retrieved from http://www.philol.vernadskyjournals.in.ua/journals/2019/ 2 2019/part 1/28.pdf [in Ukrainian].

8. Chernenko, N. I. (2016). Pedagogichni umovy realizatcii andragogichnogo pidkhodu u profesiinii pidgotovtsi robitnykiv morskogo transportu [The pedagogical conditions of the andragogical approach realization in the vocational training of maritime traffic workers]. (Extended abstract of Candidate's thesis). Kherson [in Ukrainian].

Lipshyts L. V., orcid.org/0000-0001-6443-3321

\section{USING OF THE CASE METHOD IN THE PROFESSIONAL TRAINING OF FUTURE MARINE SPECIALISTS IN TEACHING ENGLISH}

The article substantiates the need to use the case method in the professional training process of future marine specialists in teaching English. The importance of English language learning by future specialists of the maritime industry in current conditions has been determined.

It has been found that the case method is actively used at maritime education institutions, as it meets the needs of the present time and has a great potential, in particular for the professional development of the future marine specialist personality. The necessary skills of future specialists, that are formed when using the case method, such as clear fulfillment of the goals and tasks, the ability to formulate the opposite point of view, the ability to argue and defend one's opinion, thinking critically, finding the solutions in a limited time are characterized.

The author emphasizes that the purpose of applying the case method in teaching Maritime English should be reasonable and significant as working on the case should make the students be interested due to the tension of the situation, conflict and drama. It has been defined the content of the maritime case, which should reflect the learning objectives, contain dosed information so that students can quickly understand the essence of the problem and provide the necessary data to solve it. The peculiarities of work on the case, in the process of which students must use the acquired knowledge 
and show their personal qualities, such as the ability to demonstrate the level of vision of the professional situation, the level of Maritime English, etc. have been revealed.

Successive steps of work on the content of the case on a maritime topic and effective work factors, which depend on the quality of the case itself, the level of professional training of the students and the teacher's readiness are formulated. The types of the cases that should be used in Maritime English teaching are considered. The definition of the case on maritime topic as a single information complex; as a description of events that contains a specific problem situation that needs to be discussed and to have a reasoned solution has been given.

The case method as an interactive method of teaching, a method of situation analysis, which allows to bring the learning process closer to the real professional activity of marine professionals has been characterized.

Key words: case, case method, professional training, Maritime English, future marine specialists, practical lesson, teacher, skills.

Дата надходження статті: 04.11.2021 p.

Рецензент: доктор педагогічних наук, доцент Рябуха I. М.

UDC 377.1

DOI https://doi.org/10.37915/pa.vi50.313

Penza I. $V_{.}^{*}$,

orcid.org/0000-0002-8984-188X

\section{TEACHING MODULE SHIPBOARD INSPECTIONS IN MARITIME ENGLISH COURSE FOR MASTER'S DEGREE NAVIGATION FACULTY STUDENTS}

The article is devoted to the problem of teaching module Shipboard Inspections in Maritime English course for master's degree navigation faculty students. It is stated that the module is studied by future masters in the second semester being a part of a student's book Extramiler. As Maritime English syllabus is compiled in accordance with STCW requirements, professional materials suggested in the module are intertwined with grammar and vocabulary items to make students able to speak on professional issues, demonstrating English language proficiency required. Teaching Shipboard Inspections should be organized in accordance with the communicative approach and active learning strategies. The module contains two sections: Know it and Do it. Section Know it comprises 3 parts: Part A What do shipboard inspections check?, Part B What inspection documents should you be aware of? and Part $C$ What types of surveys can your ship undergo? Do itis a part providing the case to summarize knowledge on the module studied. Each part is aimed to achieve certain skill, altogether they are grouped around essential competency: to make students able to describe shipboard inspections and surveys procedures, their requirements and documents referring to them. Part A includes general overview of inspections, descriptions of Port State Control, Flag State Control, internal and external audits procedures and requirements.Part B contains the abstracts from different inspection documents, guidelines for masters, reports on inspections conducted, that include the deficiencies revealed, and checklists. Part $C$ is aimed at familiarization with the types of surveys, their purpose and frequency. The module is enriched with cases adapted by the author that are a source of authentic information to form critical thinking, integrate various language skills and generate own ideas.

Key words: module, Shipboard Inspections, Maritime English, master's degree, navigation faculty students, teaching, part, topic.

*C) Penza I. V.

U3 